Original Article

\title{
SUCCESS OF SELECTION IN TERMS OF HYGIENIC BEHAVIOR IN STRUGGLE AGAINST DWV AND VARROA
}

\author{
Kemal Karabağ ${ }^{1 *}$ \\ Ayșe Alemli ${ }^{1}$ \\ Rahșan Ivgin Tunca² \\ ${ }^{1}$ Akdeniz University, Faculty of Agriculture, Department of Agricultural \\ Biotechnology, Antalya, Turkey \\ 2Muğla Sıtkı Koçman University, Ula Ali Koçman Vocational School, Department of \\ Plant and Animal Production, Muğla, Turkey \\ *corresponding author: karabag@akdeniz.edu.tr \\ Received: 27 August 2019; accepted: 11 September 2020
}

\section{A bstract}

Many studies have reported sudden and large-scale losses in honey bee colonies. There is no precise explanation for this happening, but it may be caused by the interaction of pathogenic viruses and ectoparasite Varroa destructor. Deformed-wing virus (DWV) is common in Apis mellifera L. and has been implicated in worldwide Varroa-associated colony losses. Hygienic behavior may be one of the ways that limit $V$. destructor infestation level and DWV load. The purpose of this research was to determine whether the selection of higher hygienic behavior is effective against $V$. destructor and DWV. Workers and pupae of $A$. $\boldsymbol{m}$. anatoliaca were collected from colonies showing four generations of hygienic behaviodr, and non-hygienics were used as a control. Loads of DWV were investigated by one-step RT-qPCR, and the bottom-board method was used to allow mites count. The prevalence of DWV in pupae were higher in hygienic colonies $(69.0 \%$, average viral load 234.38 ) than control colonies (60.8\% average viral load 937.70$)$. However, the prevalence of worker bees infected with DWV was lower in hygienic colonies $(41.3 \%$, average viral load 181627.69) than in control's (66.0\%, average viral load 241982.35 ). Although the averages of the Varroa counts were significantly different for both hygienic (28.92) and control colonies (108.90), we could not find any correlation between DWV loads of both workers and pupae in this study. When all these results are evaluated, the selection performed in terms of hygienic behavior can said to have been said successful against DWV.

Keywords: A. m. anatoliaca, deformed wing virus, hygienic behavior, RT-qPCR, Varroa destructor

\section{INTRODUCTION}

The Honey bee (Apis mellifera L.) is the most important pollinator for the scientific world because of its role in pollination (Ryabov et al., 2014; McMenamin \& Genersch, 2015; Tantillo et al., 2015) and they produce such economically important products as honey, wax, pollen, propolis, royal jelly and bee venom (Popovska et al., 2018; Sforcin, Bankova, \& Kuropatnicki, 2017).

Hygienic behavior is a potential struggle mechanisms against $V$. destructor (Boecking, Bienefeld, \& Drescher, 2000; Ibrahim \& Spivak, 2006), a resistance mechanism against viruses or mites and a natural response of workers' (Harbo \& Harris, 2001; Cheruiyot et al., 2018), and is also a heritable trait, not a learned behavior (Al Toufailia et al., 2018). Resistant honey bees remove mites from the brood before bees are infected with the diseases (Gramacho \& Spivak, 2003; Al Toufailia et al., 2018), and over the last five decades this trait has been extensively studied and improved in several research and breeding programs (Spivak 1996; Harbo \& Harris, 2001). Breeding programs have shown that selection for a specific trait might also impact other traits. For example, Ibrahim et al. (2007) found fewer mites in hybrid honey bee colonies (hygienic "HYG" $X$ suppression of mite 
reproduction "SMR") compared to HYG colonies but no difference in the fertility and number of viable female offspring among the lines. These results suggest that breeding for SMR may improve multiple traits rather than just hygienic behavior. On the other hand, it was reported that bees raised for SMR show hygienic behavior and adult bees selectively remove infected pupae (Ibrahim \& Spivak, 2006). However, the benefits of improving hygienic behavior have yet to be clarified along with whether there are any costs associated with the trait at the colony level (Leclercq et al., 2017). This is also a source of concern primarily for honey-trading countries including Turkey. For over ten years, there have been numerous reports of significant losses of honey bee colonies in twenty-four worldwide (Neumann \& Carreck, 2010; Spleen et al., 2013; Steinhauer et al., 2014; McMenamin \& Genersch, 2015) including Turkey (Giray et al., 2007; van der Zee et al., 2012; Desai, Kumar, \& Currie, 2016), and the latest and unresolved crisis has been associated with bee viruses, including DWV (Organtini et al., 2017), reported up to (de Miranda, Cordoni, \& Budge, 2010; Remnant et al., 2017). Viruses considerably affect the health of honey bees and shorten their lifespan by infecting the different life stages including eggs, larvae, pupae and adults (Chen \& Siede, 2007) and also can be transmitted vertically or horizontally between colony members in a short time (Chen, Evans, \& Feldlaufer, 2006). V. destructor is the most harmful parasite for $A$. mellifera (Solignac et al., 2005), although its natural host is Apis cerana (Le Conte, Ellis, \& Ritter, 2010). Importantly, honey bee viruses and $V$. destructor are often thought to be related to colony losses in recent years (Le Conte, Ellis, \& Ritter, 2010). In the absence of $V$. destructor, many viruses of honey bee cause latent infections which have no clinical symptoms in infected bees or colonies (Gisder, Aumeier, \& Genersch, 2009; de Miranda $\&$ Genersch, 2010) because of a viral vector. The presence of $V$. destructor is associated not only with the prevalence but also with the course of DWV infection (Francis, Nielsen, \& Kryger, 2013), and in its absence the virus usually cause latent infection (Lanzi et al., 2006; Yue et al., 2007;
McMenamin et al., 2018) due to its synergy with V. destructor (Chen \& Siede, 2007; Simeunovic et al., 2014; Ryobov et al., 2014; Khongphinitbunjong et al., 2015; Di prisco et al., 2016; Nazzi \& Pennacchio, 2018; Evans \& Cook, 2018).

Although several diagnostic techniques have been used to detect honeybee viruses, it is very difficult or impossible to differentiate and quantify virus infections through field symptoms (Desai, Kumar, \& Currie, 2016). Reverse transcriptase-quantitative PCR (RT-qPCR), which is 1000 times more sensitive than ELISA and 100 times more sensitive than conventional non-nested RT-PCR (de Miranda, Cordoni, \& Budge, 2010), can be rapidly implemented in independent laboratories after the preparation of primary protocol and primer sequences (Simeunović et al., 2014). RT-qPCR has been preferred more recently with TaqMan (Cirkovic et al., 2018) due to highly reliable, fast and accurate results (Chantawannakul et al., 2006) even if a little bit expensive. In the present study, we investigated the success of the selection in terms of hygienic behavior in the struggle against DWV and Varroa in colonies which are under breeding programmes for hygienic behavior.

\section{MATERIAL AND METHODS}

\section{Sample collection}

Sampling was carried out during April 2017 in Muğla-Fethiye-Incirköy which is located at 601 meters above sea level in the south-western region of Turkey. This area was isolated for breeding Muğla honey bees to study hygienic behavior. The hygienic bee breeding programe has been carried out using the pin test (Newton \& Ostasiewski, 1986) and artificial insemination according to Laidlaw \& Page (1997) since 2013 by the Muğla Beekeping Association. Samples were provided from fifty hygienic colonies (Oskay et al., 2019), and fifty non-hygienic colonies, which were used as the control, and is Muğla honey bees ecotype ( $A$. m. anatoliaca) from this isolated area. The colonies were crowded with both forager and nursing bees, as there was intense nectar and pollen flow due to 
spring season, and they did not have symtoms of any disease. Ten worker bees and ten sealed pupa samples as a representative for colonies were taken for numbered sterile tubes from each colony. All samples were stored at $-80^{\circ} \mathrm{C}$ until further analysis.

\section{Quantifying hygienic behavior}

For the first three years starting in 2012, the hygenic bee breeding program was conducted as a project supported by by Republic of Turkey Ministry of Agriculture and Forestry General Directorate of Agricultural Research and Policies (Oskay et al., 2019). After the project was completed, the breeding program was carried out by Muğla Beekeeping Association (MAYBIR). Colonies were evaluated twice for hygienic behavior in April each year. Because cold nitrogen was not easily found in land conditions far from the city center, the pin-killed brood (PKB) assay was preferred to determine the hygienic feature levels of all the colonies in this program. The breeding program started with two-hundred colonies in an area closed to other bekeepers far away from the city center in order (Oskay et al., 2019). During the tests, 11- to 15-day-old individuals in the pupae period in 100 eyes in the hatching frames were killed by Pin and kept in hives for twenty-four hours. At the end of this period, colonies where worker bees cleaned $95 \%$ or more of the dead pupae from the eyes were determined. Hygienic behavior increased in the population from 43\% in 2012; $63 \%$ in 2013; $91.7 \%$ in 2014 to $96.8 \%$ in 2015 (Oskay et al., 2019). The samples were collected in 2017, and MAYBIR announced the hygenic behavior ratio as $97 \%$ from. Anti-varroa treatment by Rulamit VA (seven doses of smoke were pressed from the flight hole of each hive) was applied in early or mid February according to seasons in the Hygenic breeding programme and repeated three times with a three-day interval in November and February.

\section{Determination of Varroa Mites}

To determine the varroa loads of sampled colonies, the bottom board method was used (Dietemann et al., 2013). After applying acaraside (rulamit-containing incense), mites dropped to white sheets of paper that laid on the bottom board in the hygienic and non-hygienic hives. The sheets were collected, sealed in plastic bags and brought to the laboratory. The mites were counted using a magnifying glass and saved in the laboratory.

\section{Total RNA extraction}

Total RNAs of each bee and pupae were extracted using high pure viral nucleic acid kit version 19 (Roche, Switzerland) according to the manufacturer's protocol. Ten worker bees and ten pupae samples from each colony were extracted separately as a bulk. Each bulk sample was crushed by a hand drill and homogenized in a $5 \mathrm{ml}$ microcentrifuge tube. Then the RNA was extracted, and the samples were measured using the BioDropDuo (BioDrop Ltd, UK) and checked using gel electrophoresis (Reliant Gel systems). The RNA samples found to be sufficient in terms of quality and quantity ranging from $239.20 \mathrm{ng} / \mathrm{ul}$ to $343.30 \mathrm{ng} / \mathrm{ul}$ from hygienic (worker=46 and pupa=42) and non-hygienic (worker $=50$ and pupa=46) colonies were stored at $-80^{\circ} \mathrm{C}$ until further use.

\section{Reverse Transcriptase-qPCR}

For reverse transcription, one-step RT-qPCR (reverse transcriptase quantitative polymerase chain reaction) assay was performed using the Real Time ready RNA virus master kit (Roche). TaqMan technology utilizing a fluorescent probe (FAM-TAMRA) was used to identify the amount of DWV, and the LightCycler 96 (Roche) instrument was used for fluorescence detection. The RT-qPCR reactions were performed in 20 $\mu l$ volumes containing $0.8 \mu \mathrm{PP} \operatorname{mix}(0.1 \mu 100$ pmol each of the gene-specific forward and the reverse primer, $0.15 \mu \mathrm{l} 20 \mathrm{pmol}$ each of the genespecific probe, and $1.65 \mu$ l PCR-grade $\left.\mathrm{H}_{2} \mathrm{O}\right), 0.3 \mu \mathrm{l}$ enzyme blend (50x), $2.5 \mu$ ready buffer $(5 x), 2$ $\mu l$ RNA and $4.4 \mathrm{H} \mathrm{H}_{2} \mathrm{O}$. The thermocycling profile for this assay was as follows: 5 min at $50^{\circ} \mathrm{C}$ and $5 \mathrm{~min} 58^{\circ} \mathrm{C}$ for $\mathrm{cDNA}$ synthesis, $1 \mathrm{~min}$ at $95^{\circ} \mathrm{C}$ for inactivation of the reverse transcriptase following 40 cycles of $10 \mathrm{sec}$ at $95^{\circ} \mathrm{C}$ for denaturation and $30 \mathrm{sec}$ at $60^{\circ} \mathrm{C}$ for annealing and 
data collection. For assays, a six-fold dilution series $\left(10^{4}-10^{9}\right.$ copies) of synthetic positive control of a known concentration was also run on each reaction plate to constitute a standard curve (Sup. Fig. 1). Calculating the $R$ value as 1 indicates that the 6-fold solution we use is sufficient. We used a null reaction mix as a negative control, and a for second time we checked out the DWV positive samples using RT-qPCR in order to confirm the quantitation. Also, DWV load per colony was determined by taking the average of the calculated values as a result of both RT-qPCR.

\section{Statistical Analysis}

RT-qPCR amplification results were taken into account of the standard curve of the samples designed as the synthetic positive control. Here, the number of amplified viruses in each sample was calculated according to the six-fold dilution of known values as $10^{4}-10^{9}$ (Sup. Fig. 1). All quantitative data were subjected to the normal distribution test (Kolmogorov-Smirnov). Indepentent t-test was performed for $\mathrm{Cq}$ (quantification cycle) and Varroa data set showed normal distribution. However, when virus-free samples were taken at zero value, high standard deviations were calculated for the data set. For this reason the Mann Whitney $U$ test with medians was used in SPSS (23v.) to compare the hygienic and nonhygienic colonies according to DWV loads at a level of worker bees and pupae (Tab. 1). Pearson correlation test was used to determine if there was any relationship between the viral loads and mite loads of the colonies for both worker bees and pupae. Also, percentages of colonies infected with DWV were compared with the chi-square test according to both worker bees and pupae (Tab. 1).

\section{RESULTS}

To determine whether the selection in terms of hygienic behavior is effective on $V$. destructor and DWV, $A$. m. anatoliacahoney bee workers and pupae samples were collected from the Mugla region showing four generations of hygienic and unhygienic behavior of the colony in Turkey. DWV was detected in most of the studied samples, and the DWV loads and Cq values in RT-qPCR for both worker bees and pupae in the control and hygienic colonies were summarized graphically in the Fig. 1a, 1b. Fig. 1a shows that the DWV loads in the worker bees and pupae taken from the control group are a little higher than in the hygienic colonies. Moreover, as seen clearly in Fig. 1b both the worker bees and the pupae taken from the control group gave signals earlier in terms of DWV in RT-qPCR than the samples taken from the hygienic group. As seen from Tab. 1, DWV loads $(p<0.01)$ and Cq values $(p<0.05)$ in worker bees are significantly different between the hygienic and control groups. Interestingly, the prevalence of DWV in
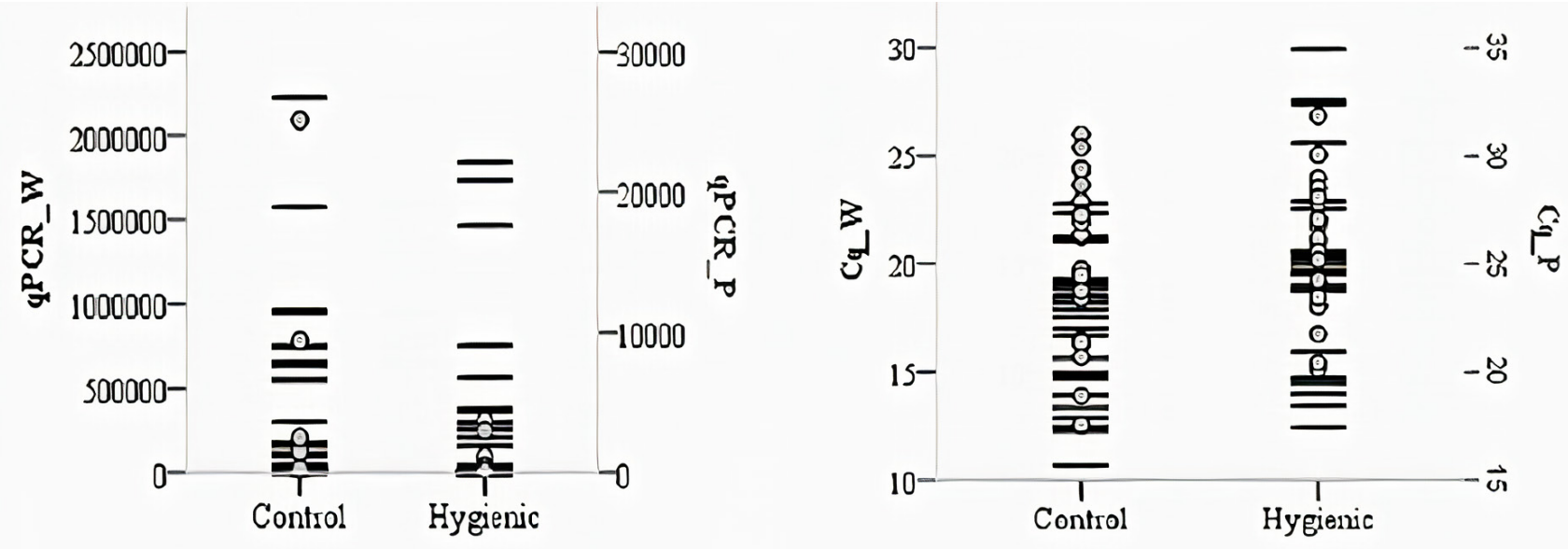

a

b

Fig. 1. DWV loads (a) and the number of quantification cycles (b) of worker bees and pupae from control and hygienic colonies regarding qPCR. By black lines and circles, respectively represent worker bees and pupae.

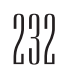


Table 1.

Statistical comparison of control and hygienic colonies in terms of DWV loads, Cq values, prevalence of DWV, and Varroa loads

\begin{tabular}{cccccccc}
\hline & & N & $\begin{array}{c}\text { Mean } \pm \text { St.E } \\
\text { RT-qPCR }\end{array}$ & N & $\begin{array}{c}\text { Mean } \pm \text { St.E } \\
\text { Cq }\end{array}$ & $\begin{array}{c}\% \\
\text { Prevelances }\end{array}$ & $\begin{array}{c}\text { Varroa } \\
\text { Counts }\end{array}$ \\
\hline \multirow{2}{*}{ H } & Worker & 46 & $181627.69 \pm 64074.74^{* *}$ & 19 & $20.10 \pm 1.15^{*}$ & 41.3 & $28.92 \pm 5.41^{* *}$ \\
& Pupa & 42 & $234.38 \pm 112.34$ & 29 & $26.36 \pm 0.55$ & 69.0 & \\
\multirow{2}{*}{ C } & Worker & 50 & $241982.35 \pm 65972.63^{* *}$ & 33 & $17.13 \pm 0.59^{*}$ & 66.0 & $108.90 \pm 9.80^{* *}$ \\
& Pupa & 46 & $937.70 \pm 578.55$ & 28 & $25.56 \pm 0.66$ & 60.8 & \\
\hline
\end{tabular}

H: Hygienic, C: Control

${ }^{*, * *}$ : Means with different superscripts are significantly different in terms of $p<0.05 p<a n d 0.01$, respectively.

pupae (69.0\%) taken from the hygienic colonies is higher than the pupae taken from control colonies (60.8\%). However, the number of worker bees (66.0\%) infected with DWV from the control colonies was higher than that from the hygienic colonies (41.3\%), and these differences with regard to virus prevalence between hygienic and control colonies were calculated to be significant by using Chi-square test ( $p<0.01)$. According to t-test results, the averages of Varroa counts for the hygienic colonies (28.92) was significantly $(p<0.01)$ lower than that of the control colonies (108.90). However, we could not find any correlation between Varroa loads and DWV loads of both worker and pupae in this study.

\section{DISCUSSION}

In recent decades in Turkey, Gülmez, Bursalı, \& Tekin (2009) and Tozkar et al. (2015) have studied Deformed Wing Virus, and Muz \& Muz (2009, 2017) studied how both DWV and V. destructor interaction caused colony collapse in Hatay and Tekirdağ regions. There have been more studies about the coexistence of DWV and Varroa world-wide (Martin 2001; Berényi et al., 2006; Yue et al., 2007; Nielsen, Nicolaisen, \& Kryger, 2008; Gisder, Aumeier, \& Genersch, 2009; Locke, Forsgren, \& de Miranda, 2014). DWV has been shown to have different concentrations in healthy colonies in the highest percentage of pooled samples of worker bees and at high levels in unhealthy colonies (Desai, Kumar, \& Currie, 2016). DWV was the most prevalent virus in Austria, present in 91\% of samples (Berényi et al., 2006), and Nielsen et al., (2008) reported that hives with a high rate of winter mortality had 57\% DWV infection. Baker \& Schroeder (2008) informed of a 97\% prevalence of DWV in the $A$. mellifera L. colonies without any indication of infection. RT-qPCR has been preferred in many studies due to its being reliable, specific, and sensitive to determining honey bee viruses (Cirkovic et al., 2018; Nazzi, \& Pennacchio, 2018). Simeunović et al. (2014) obtained a high frequency of DWV (76.4\%) using TaqMan-based real-time RT-PCR technique in asymptomatic colonies. Although, there was no sign of any disease in the colonies examined in our study, the number and prevalence of colonies infected with DWV were calculated to be considerably high using TaqMan-based real-time RT-PCR (Tab. 1).

A comparison of colonies showed that DWV prevalence was higher in pupae $(69.0 \%)$ but in contrast lower in worker bees (41.3\%) from hygienic colonies (Tab. 1). This supports a previous study by Gauthier et al. (2007) who suggested that pupae were more susceptible to DWV replication and found differences between DWV loads in adults and pupae, which might result from the fact that diseased adults have much shorter lifespans. Moreover, depending on the higher hygienic behavior of hygienic colonies, bees could remove the infected pupae from colonies, and by doing so, the number of healthy adults might be higher which would contribute to a lowering of virus concentration in hygienic colonies Gauthier et al. (2007). We also 
found the amount of DWV of hygienic colonies to be lower than the control (Tab. 1). Yañez et al., (2015) and Li et al., (2012) drew attention to the higher prevalence of DWV in $A$. mellifera compared to $A$. cerana, which Chanpanitkitchote et al. (2018) interpreted as a strong ability of $A$. cerana to resist both viruses and mites. Rsistance, similar to that of $A$. cerana against DWV and Varroa, can also be demonstrated by A. mellifera, which has been developed in terms of hygienic behavior.

Spivak \& Reuter (1998) compared hygienically selected and unselected $A$. m. ligustica colonies and showed that hygienically behaving bees had been successfully removed from frozen slaughtered pupae and parasites and that brood diseases were at very low levels or not at all. It has been reported that honey bee colonies can be easily selected for hygienic behavior as a result of hygienic behavior tests conducted by land experiments (Spivak \& Gilliam, 1998) or direct pathogen (Gilliam et al., 1988) and mite (Boecking \& Drescher, 1990) practices. However, all the effects of hygienic behavior have not yet been fully explained.

The virus prevalence was unexpectedly higher at the pupae phase in the hygienic colonies in the present study. While hygienic colonies have fewer viruses in their worker bees and pupae, it is not known why the virus prevalence is higher in terms of pupae in hygienic colonies than the control (Tab. 1). While there are a few possible responses to explain this situation, the sperm pool may be used in artificial insemination to obtain hygienic colonies. Namely, when sperm is collected, the somatic cells of virus-infected drones might also be collected. Even if there is no virus in the sperm, somatic cells can carry the infection to the pool. If there is an infection even in a single drone, the sperm pool used to fertilize the queens may be contaminated. More populations may have been infected with viruses due to fertilized queens using the sperm pool in the hygienic colonies. Results that support this have been pointed out in previous studies that viruses can translate horizontally through individuals in the same generation and can be transferred from one generation to another vertically through their queens (Chen, Evans, \& Feldlaufer, 2006; Yue et al., 2007; Tantillo et al., 2015). The venereal passing of DWV through artificial insemination with infected semen in DWV-free virgin queens has been already testified fully by de Miranda \& Fries (2008). The key result of the present study may be an indication that hygienic colonies remove the infected pupae from the hive and thereby reduce the spread of the virus in adult bees, and if so, this is a success of hygienic colony breeding.

Like all other bee viruses, DWV is harmful for beekeeping and is considered the most serious secondary pathogen associated with varroosis (Yue \& Genersch, 2005), although many studies have concluded that the Varroa mite is a vector for honeybee viruses including DWV (Tentcheva et al., 2006; Gauthier et al., 2007; Carreck, Ball, \& Martin, 2010; Simeunovic et al., 2014). Because we could not reveal the exact number of mites in the colonies using the bottom-board method, we could not find any correlation between Varroa loads and DWV loads of both workers and pupae in this study. The selected colonies were shown to be better in terms of virus and Varroa due to increased hygienic behavior in this study, and as a result the selection for hygienic behavior is effective on viruses and mite loads. On the other hand, in this project, the surveyed region is an important beekeeping center, because Turkey is one of the world's largest honey producers (Can et al., 2015) and also because $90 \%$ of the world's pine honey is produced in the Muğla region (Miguel, Pukkala, \& Yesil, 2014; Özkök et al., 2017). In addition, the distribution and relative concentration of viruses within bee colonies in Muğla are still poorly understood. For these reasons, these findings may be important for researchers and be evaluated as an indicator for practices.

\section{ACKNOWLEDGMENTS}

The authors declare that they have no conflict of interest.

This study was supported by the Akdeniz University Scientific Research Projects Coordination Unit, under project number of FYL-2017- 
2448. Selection studies have been performed by the Muğla Beekeeping Association (MAYBIR) and founded by grant TAGEM-11/AR-GE/13.

\section{REFERENCES}

Al Toufailia, H., Evison, S. E. F., Hughes, W.O.H., \& Ratnieks, F.L.W. (2018). Both hygienic and non-hygienic honeybee, Apis mellifera, colonies remove dead and diseased larvae from open brood cells. Philosophical Transactions of the Royal Society BiBiological Sciences, 371751), 20170201. https://doi.org/10.1098/ rstb.2017.0201

Baker, A.C., \& Schroeder, D.C. (2008). The use of RNA-dependent RNA polymerase for the taxonomic assignment of Picorna-like Viruses (order Picornavirales) infecting Apis melliferaL. populations. Virology Journal, 5(1), 10. DOl: 10.1186/1743-422X-5-10

Berényi, O., Bakonyi, T., Derakhshifar, I., Köglberger, H., Nowotny, N. (2006). Occurrence of six honeybee viruses in diseased Austrian Apiaries. Applied and Environmental Microbiology, 72(4), 2414-2420. https:// doi.org/10.1128/AEM.72.4.2414-2420.2006\#aff-1

Boecking, O., \& Drescher W. (1990). The reaction of worker bees in different Apis mellifera colonies to Varroa infested brood cells, in: Ritter W. (Ed.). In Proceedings of the International Symposium on Recent Research on Bee Pathology, (p. 41-42). Gent- Belgium.

Boecking, O., Bienefeld, K., \& Drescher, W. (2000). Heritability of the Varroa-specific hygienic behaviour in honey bees (Hymenoptera: Apidae). Journal of Animal Breeding and Genetics, 1776), 417-424. DOl:10.1046/j.1439-0388.2000.00271.x

Can, Z., Yildiz, O., Sahin, H., Akyuz Turumtay, E., Silici, S., Kolayli, S. (2015). An investigation of Turkish honeys: Their physico-chemical properties, antioxidant capacities and phenolic profiles. Food Chemistry, 180, 133-141. http://dx.doi.org/10.1016/j. foodchem.2015.02.024

Carreck, N.L., Ball, B.V., \& Martin, S.J. (2010). Honey bee colony collapse and changes in viral preva- lence associated with Varroa destructor. Journal of Apicultural Research, 49(1), 93-94. D0l: 10.3896/ IBRA.1.49.1.13

Chanpanitkitchote, P., Chen, Y., Evans, J. D., Li, W., Li, J., Hamilton, M., Chantawannakul, P. (2018). Acute bee paralysis virus occurs in the Asian honey bee Apis cerana and parasitic mite Tropilaelaps mercedesae. Journal of Invertebrate Pathology, 151, 131-136. https://doi.org/10.1016/j.jip.2017.11.009

Chantawannakul, P., Ward, L., Boonham, N., \& Brown, M. (2006). A scientific note on the detection of honeybee viruses using real-time PCR (TaqMan) in Varroa mites collected from a Thai honeybee (Apis mellifera) apiary. Journal of Invertebrate Pathology, 97(1), 69-73. https://doi.org/10.1016/j.jip.2005.11.001

Chen, Y.P., Evans, J., \& Feldlaufer, M. (2006). Horizontal and vertical transmission of viruses in the honey bee, Apis mellifera. Journal of Invertebrate Pathology, 92(3), 152-159. https://doi.org/10.1016/j. jip.2006.03.010

Chen, Y.P., \& Siede, R. (2007). Honey bee viruses. Advances in Virus Research, 70, 33-80. https://dx.doi. org/10.1016/S0065-3527(07)70002-7

Cheruiyot, S.K., Michael, H., Lattorff, G., KahuthiaGathu, R., Mbugi, J.P., Muli. E. (2018). Varroa - specific hygienic behavior of Apis mellifera scutellata in Kenya. Apidologie, 49(4),439-449. https://doi. org/10.1007/s13592-018-0570-6

Cirkovic, D., Stevanovic, J., Glavinic, U., Aleksic, N., Djuric, S., Aleksic, I., Stanimirovic, Z. (2018). Honey bee viruses in Serbian colonies of different strength. Peer /, 6:e5887. https://doi.org/10.7717/peerj.5887

de Miranda, J.R., Cordoni, G., \& Budge, G. (2010). The Acute Bee Paralysis Virus-Kashmir Bee VirusIsraeli Acute Paralysis Virus complex. Journal of Invertebrate Pathology, 103, S30-S47. https://doi. org/10.1016/j.jip.2009.06.014

de Miranda, J. R., \& Fries, I. (2008). Venereal and vertical transmission of deformed wing virus in honeybees (Apis mellifera L.). Journal of Invertebrate 
Pathology, 98(2), 184-189. https://doi.org/10.1016/j. jip.2008.02.004

de Miranda, J.R., \& Genersch, E. (2010). Deformed Wing Virus. Journal of Invertebrate Pathology, 103, s48-S61. https://doi.org/10.1016/j.jip.2009.06.012

Desai, S.D., Kumar, S., \& Currie, R.W. (2016). Occurrence, detection, and quantification of economically important viruses in healthy and unhealthy honey bee (Hymenoptera: Apidae) colonies in Canada. The Canadian Entomologist, 148(1), 22-35. https://doi.or g/10.1080/0005772X.2012.11417501

Dietemann V., Nazzi F., Martin S. J., Anderson D. L." Locke B., Delaplane K. S., Ziegelmann B. (2013). Standard methods for varroa research. Journal of Apicultural Research, 52(1), 1-54. https://doi.org/10.3896/ ibra.1.52.1.09

Di Prisco, G., Annoscia, D., Margiotta, M., Ferrara, R., Varricchio, P., Zanni, V., ... Pennacchio, F. (2016). A mutualistic symbiosis between a parasitic mite and a pathogenic virus undermines honey bee immunity and health. Proceedings of the National Academy of Sciences, 113(12), 3203-3208. https://doi. org/10.1073/pnas.1523515113

Evans, J.D., \& Cook, S.C. (2018). Genetic and physiology of Varroa mites. Current Opinion in Insect Science, 26, 130-135. https://doi.org/10.1016/j. cois.2018.02.005

Francis, R.M., Nielsen, S.L., \& Kryger, P. (2013). Varroavirus interaction in collapsing honey bee colonies. PLOS ONE, 8(3), e57540, https://doi.org/10.1371/ journal.pone.0057540

Gauthier, L., Tentcheva, D., Tournaire, M., Dainat, B., Cousserans, F., Colin, M.E., Bergoin, M. (2007). Viral load estimation in asymptomatic honey bee colonies using the quantitative RT-PCR technique. Apidologie, 38(5), 426-435. https://doi.org/10.1051/ apido:2007026

Gilliam, M., Taber III, S. Lorenz, B.J., \& Prest D. B. (1988). Factors affecting development of chalkbrood disease in colonies of honey bees, Apis mellifera, fed pollen contaminated with Ascosphaera apis. Journal of Invertebrate Pathology, 52(2), 314-325. https:// doi.org/10.1016/0022-2011(88)90141-3

Giray, T., Cakmak, I., Aydin, L., Kandemir, I., Inci, A., Oskay, D.,... Kence, A. (2007). Preliminary survey results on 2006-2007 colony losses in Turkey. Uludag Bee Journal, 73 ), 102-108.

Gisder, S., Aumeier, P., \& Genersch, E. (2009). Deformed Wing Virus: replication and viral load in mites (Varroa destructor). Journal of General Virology, 90(2), 463467. https://doi.org/10.1099/vir.0.005579-0

Gramacho, K.P., \& Spivak, M. (2003). Differences in olfactory sensitivity and behavioral responses among honey bees bred for hygienic behavior. Behavioral Ecology and Sociobiology, 54(5), 472-479. https:// doi.org/10.1007/s00265-003-0643-y

Gülmez, Y., Bursall, A., \& Tekin, S. (2009). First molecular detection and characterization of Deformed wing virus (DWV) in honeybees (Apis mellifera L.) and mite (Varroa destructor) in Turkey. African Journal of Biotechnology, 8(16), 3698-3702.

Harbo, J. R., \& Harris, J. W. (2001). Resistance to Varroa destructor (Mesostigmata: Varroidae) when miteresistant queen honey bees (Hymenoptera: Apidae) were free-mated with unselected drones. Journal of Economic Entomology, 94(6), 1319-1323. https://doi. org/10.1603/0022-0493-94.6.1319

Ibrahim, A., \& Spivak, M. (2006). The relationship between hygienic behavior and suppression of mite reproduction as honey bee (Apis mellifera) mechanisms of resistance to Varroa destructor. Apidologie, 371), 31-40. DOl: 10.1051/apido:2005052

Ibrahim, A., Reuter, G.S., \& Spivak, M. (2007). Field trial of honey bee colonies bred for mechanisms of resistance against Varroa destructor. Apidologie, 38(1), 67-76. DOl: 10.1051/apido:2006065

Khongphinitbunjong, K., de Guzman, L. I., Tarver, M. R., Rinderer, T. E., Chen, Y., Chantawannakul, P. (2015). Differential viral levels and immune gene expression in three stocks of Apis mellifera induced by differ- 
ent numbers of Varroa destructor. Journal of Insect Physiology, 72, 28-34. http://dx.doi.org/10.1016/j.jinsphys.2014.11.005

Laidlaw, H.H., \& Page, R. E. (1997). Queen rearing and bee breeding. Wicwas Press.

Lanzi, G., de Miranda, J.R., Boniotti, M.B., Cameron, C.E., Lavazza, A., Capucci, L., ... Rossi, C. (2006). Molecular and biological characterization of Deformed wing virus of honeybees (Apis mellifera L.). Journal of Virology, 80(10), 4998-5009. D0l: 10.1128/ JVI.80.10.4998-5009.2006

Leclercq, G., Pannebakker, B., Gengler, N., Nguyen, B.K., Francis, F. (2017). Drawbacks and benefits of hygienic behavior in honey bees (Apis mellifera L.): a review. Journal of Apicultural Research, 56(4), 366375. https://doi.org/10.1080/00218839.2017.1327 938

Le Conte, Y., Ellis, M., \& Ritter, W. (2010). Varroamites and honey bee health: can Varroa explain part of the colony losses? Apidologie, 47(3), 353-363. https:// doi.org/10.1051/apido/2010017

Li, J., Qin, H., Wu, J., Sadd, B.M., Wang, X., Evans, J.D., ... Chen, Y. (2012). The prevalence of parasites and pathogens in Asian honeybees Apis cerana in China. PloS ONE, 711). e47955, http://dx.doi.org/10.1371/ journal.pone.0047955

Locke, B., Forsgren, E., \& de Miranda, J.R. (2014). Increased tolerance and resistance to virus infections: a possible factor in the survival of Varroa destructor-resistant honey bees (Apis mellifera). Plos ONE, 9(6),e99998 https://doi.org/10.1371/journal. pone.0099998

Martin, S.J. (2001). The role of Varroa and viral pathogens in the collapse of honeybee colonies: a modeling approach. Journal of Applied Ecology, 38(5), 1082-1093. https://doi.org/10.1046/j.13652664.2001.00662.x

McMenamin, A.1., \& Genersch, E. (2015). Honey bee colony losses and associated viruses. Current Opinion in Insect Science, 8, 121-129. http://doi.

\section{org/10.1016/j.cois.2015.01.015}

McMenamin, A., Daughenbaugh, K., Parekh, F., Pizzorno, M., Flenniken, M. (2018). Honey Bee and Bumble Bee Antiviral Defense. Viruses, 108), 395. https:// doi.org/10.3390/v10080395

Miguel, S., Pukkala, T., \& Yesil, A. (2014). Integrating Pine Honeydew Honey Production into Forest Management Optimization. European Journal of Forest Research, 133(3), 423-432. https://doi.org/10.1007/ s10342-013-0774-2

Muz, D.P., \& Muz, M.N. (2009). Survey of the occurrence of Deformed Wing Virus and multiple parasites of queens (Apis mellifera L.) in apiaries with collapsed colonies in Hatay, Turkey. Journal of Apicultural Research, 48(3), 204-208. D0l: 10.3896/ IBRA.1.48.3.09

Muz, D.P., \& Muz, M.N. (2017). Investigation of Some Pathogens "Colony Loss Syndrome" Resembled Losses Apiaries in Tekirdağ. Kocatepe Veterinary Journal, 10(1), 21-28. DOl: 10.5578/kvj.53858

Nazzi, F., \& Pennacchio, F. (2018). Honey Bee Antiviral Immune Barriers as Affected by Multiple Stress Factors: A Novel Paradigm to Interpret Colony Health Decline and Collapse. Viruses, 1044), 159. DOl:10.3390/v10040159

Neumann, P., \& Carreck, N.L. (2010). Honey bee colony losses. Journal of Apicultural Research, 49(1), 1-6. DOl: 10.3896/IBRA.1.49.1.01

Newton, D., \& Ostasiewski, N. (1986). A simplified bioassay for behavioral resistance to American Foulbrood in honey bees (Apis mellifera L.). American Bee Journal, 126(4), 278-281.

Nielsen, S.L., Nicolaisen, M., \& Kryger, P. (2008). Incidence of acute bee paralysis virus, black queen cell virus, chronic bee paralysis virus, deformed wing virus, kashmir bee virus and sacbrood virus in honey bees (Apis mellifera) in Denmark. Apidologie, 39(3), 310-314. https://doi.org/10.1051/apido:2008007

Organtini, L. J., Shingler, K. L., Robert, E. Ashley, R. 
E., Capaldi, E. A., Durrani, K., ... Susan H. S. (2017). Honey Bee Deformed wing virus Structures Reveal that Conformational Changes Accompany Genome Release. Journal of Virology, 97(2), e01795. DOl: 10.1128/JVI.01795-16

Oskay, D., Kükrer, M., \& Kence, A., (2019) Development of Resistance to American Fool Brood Diseases on Muğla Honey Bee (Apis mellifera anatoliaca). Arıclık Araştırma Dergisi I Journal of Apiculture Research, 77(1), 8-20.

Özkök, A., Sorkun, K., Çakıroğulları, G. C.., Yağlı, H. G., Alsan, I., Bektaş, B., Kılıc, D. (2017). Dioxin analysis in pine honey from Turkey. Acta Biologica Szegediensis, 67(1), 69-75.

Popovska, D., Dimitrov, L., Golubovski, M., Uzunov, A., Brodschneider, R., Andonov, S. (2018). Pioneer Efforts for Estimation of the Economic Impact of Honey Bee Colony Losses in the Republic of Macedonia. Monitoring Workshop, (p.7-8), Nitra-Slovakia.

Remnant, E..., Shi, M., Buchmann, G., Blacquiere, T., Holmes, E.C., Beekman, M., Ashe, A. (2017). A diverse Range of Novel RNA Viruses in Geographically Distinc Honey Bee Populations. Journal of Virology, 97(16),1-19. DOl: 10.1128/JVI.00158-17

Ryabov, E. V., Wood, G. R., Fannon, J. M., Moore, J. D., Bull, J. C., Chandler, D., ... Evans, D. J. (2014). A virulent strain of Deformed wing virus (DWV) of honeybees (Apis mellifera) prevails after Varroa destructormediated, or in vitro, transmission. PLoS pathogens, 196), el004230. https://doi.org/10.1371/journal. ppat.1004230

Sforcin, J. M., Bankova, V., \& Kuropatnicki, A. K. (2017). Medical benefits of honeybee products. EvidenceBased Complementary and Alternative Medicine, 2017.https://doi.org/10.1155/2017/2702106

Simeunović P., Stevanović J., Vidanović D., Nišavić ]., Radović D., Stanišić L., Stanimirović Z. (2014). A Survey of Deformed wing virus and Acute Bee Paralysis Virusin Honey Bee Colonies from Serbia Using Real-Time RT-PCR. Acta Veterinaria-Beograd, 64(1), 81-92. DOl: 10.2478/acve-2014-0009
Solignac, M., Cournet, J.M., Vautrin, D., Le Conte, Y., Anderson, D., Evans, ... ... Navajas, M. (2005). The invasive Korea and Japan types of Varroa destructor, ectoparasitic mites of the Western honeybee (Apis mellifera), are two partly isolated clones. Proceedings of the Royal Society B: Biological Sciences, 272(1561), 411-419. DOl: 10.1098/rspb.2004.2853

Spivak, M. (1996). Honey bee hygienic behavior and defense against Varroa jacobsoni. Apidologie. 274), 245-260. https://doi.org/10.1051/apido:19960407

Spivak, M., \& Gilliam, M. (1998). Hygienic behaviour of honey bees and its application for control of brood diseases and Varroa mites. Part II. Studies on hygienic behavior since the Rothenbuhler Era, Bee World, 79(4), 169-186. D0l:10.1080/000577 2X.1998.11099408

Spivak M., \& Reuter G.S. (1998). Performance of hygienic honey bee colonies in a commercial apiary. Apidologie, 29(3), 291-302. D0l:10.1051/apido:19980308

Spleen, A. M., Lengerich, E. J., Rennich, K., Caron, D., Rose, R., Pettis, J. S., ... Lee, K. (2013). A national survey of managed honey bee 2011-12 winter colony losses in the United States: results from the Bee Informed Partnership. Journal of Apicultural Research, 52(2), 44-53. https://doi.org/10.3896/IBRA.1.52.2.07

Steinhauer, N. A., Rennich, K., Wilson, M. E., Caron, D. M., Lengerich, E. J., Pettis, J. S., ... VanEngelsdorp, D. (2014). A national survey of managed honey bee 2012-2013 annual colony losses in the USA: results from the Bee Informed Partnership. Journal of Apicultural Research, 53(1), 1-18. https://doi.org/10.3896/ IBRA.1.53.1.01

Tantillo, G., Bottaro, M., Di Pinto, A., Martella, V., Di Pinto, P., Terio, V. (2015). Virus infections of honeybees Apis mellifera. Italian Journal of Food Safety, 4(3), 157-168. https://doi.org/10.4081/ijfs.2015.5364

Tentcheva, D., Gauthier, L., Bagny, L., Fievet, J., Dainat, B., Cousserans, F.,... Bergoin, M. (2006). Comparative analysis of Deformed wing virus (DWV) RNA in Apis mellifera and Varroa destructor. Apidologie, 371), 


\section{J. APRC. SCLI. VOL. 64 NO. 2 ?QZZ}

\section{1-50. DOl: 10.1051/apido:2005057}

Tozkar, C.Ö., Kence, M., Kence, A., Huang, Q., Evans, J.D. (2015). Metatranscriptomic analyses of honey bee colonies. Frontiers in Genetics, 6, 100. DOl: 10.3389/ fgene.2015.00100

Van der Zee, R., Pisa, L., Andonov, S., Brodschneider, R., Charrière, J. D., Chlebo, R., ... Gray, A. (2012). Managed honey bee colony losses in Canada, China, Europe, Israel and Turkey, for the winters of 2008-9 and 2009-10. Journal of Apicultural Research, 57(1), 100-114. https://doi.org/10.3896/IBRA.1.51.1.12

Yañez, O., Zheng, H.-Q., Su, X.-L., Hu, F.-L., Neumann, P., Dietemann, V. (2015). Potential for virus transfer between the honey bees Apis mellifera and A. cerana. Journal of Apicultural Research, 54(3), 179-191. http://dx.doi.org/10.1080/00218839.2015.1128145
Yue, C., \& Genersch, E. (2005). RT-PCR analysis of Deformed wing virus in honeybees (Apis mellifera) and mites (Varroa destructor). Journal of General Virology, 86(12), 3419-3424. D0l: 10.1099/vir.0.81401-0

Yue, C., Schröder, M., Gisder, S., \& Genersch, E. (2007). Vertical-transmission routes for Deformed wing virus of honeybees (Apis mellifera). Journal of General Virology, 88(8), 2329-2336. DOl: 10.1099/ vir.0.83101-0 


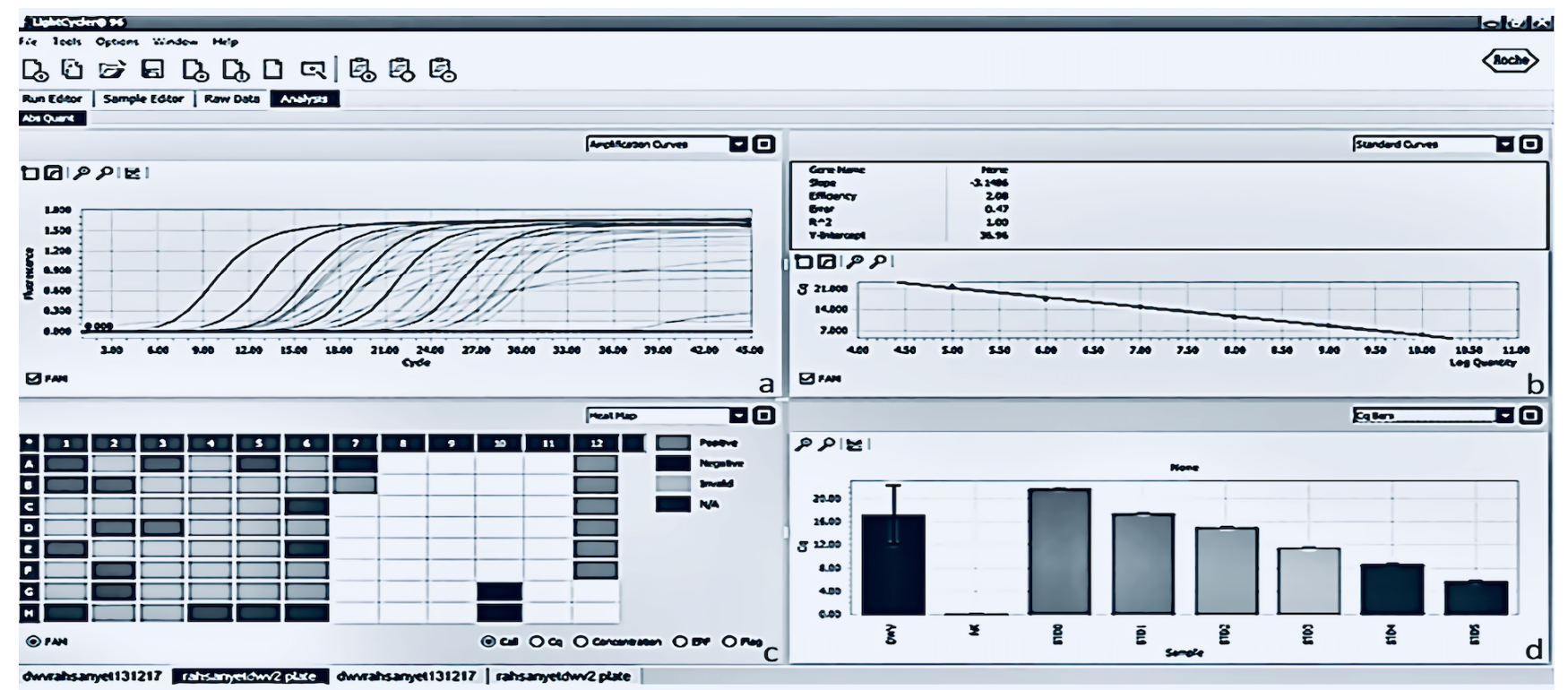

Supplementary Figure 1. A sample of reverse transcriptase-qPCR amplification Windows belong to DWV determined in this study. a) Amplification curves of DWV positive samples and folds. b) The standard curve is an indication of the reliability of the results. c) Heat map: Gray colored boxes show positive samples. d) Cq bars indicate quantification of DWV positive samples, negative control, and synthetic standard definite folds, respectively, from left to right. 